Article

\title{
Piperine Inhibits TGF- $\beta$ Signaling Pathways and Disrupts EMT-Related Events in Human Lung Adenocarcinoma Cells
}

\author{
Leonardo Marques da Fonseca ${ }^{1,+}$, Lucas Rodrigues Jacques da Silva ${ }^{1,+}$, \\ Jhenifer Santos dos Reis ${ }^{1}$, Marcos André Rodrigues da Costa Santos ${ }^{1}$, \\ Victoria de Sousa Chaves ${ }^{1}$, Kelli Monteiro da Costa ${ }^{1}$, Julliana de Nazareth Sa-Diniz ${ }^{1}$, \\ Celio Geraldo Freire de Lima ${ }^{1}$, Alexandre Morrot ${ }^{2,3}$, Tatiany Nunes Franklim ${ }^{4}$, \\ Douglas Chaves de Alcântara-Pinto ${ }^{4}$, Marco Edilson Freire de Lima ${ }^{4}{ }^{\mathbb{D}}$, Jose Osvaldo Previato ${ }^{1}$,

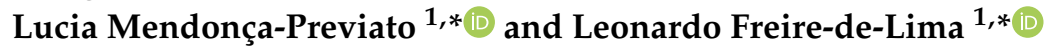 \\ 1 Laboratório de Glicobiologia, Instituto de Biofisica Carlos Chagas Filho, Universidade Federal do Rio de \\ Janeiro, Rio de Janeiro RJ 21941-902, Brazil; lfonseca@biof.ufrj.br (L.M.d.F.); lucasrjs@hotmail.com (L.R.J.d.S.); \\ jhnffrrs8@gmail.com (J.S.d.R.); rodrigues8mr@gmail.com (M.A.R.d.C.S.); \\ sousavictoria97@gmail.com (V.d.S.C.); kellimc85@gmail.com (K.M.d.C.); \\ jullianawinners@gmail.com (J.d.N.S.-D.); celio@biof.ufrj.br (C.G.F.d.L.); previato@biof.ufrj.br (J.O.P.) \\ 2 Faculdade de Medicina, Universidade Federal do Rio de Janeiro, Rio de Janeiro RJ 21941-902, Brazil; \\ alexandre.morrot@ioc.fiocruz.br \\ 3 Instituto Oswaldo Cruz, FIOCRUZ, Rio de Janeiro RJ 21040-360, Brazil \\ 4 Instituto de Química, Universidade Federal Rural do Rio de Janeiro, Seropédica RJ 23851-970, Brazil; \\ tnfranklim@gmail.com (T.N.F.); douglasdoti@hotmail.com (D.C.d.A.-P.); marco@ufrrj.br (M.E.F.d.L.) \\ * Correspondence: luciamp@biof.ufrj.br (L.M.-P.); leolima@biof.ufrj.br (L.F.-d.-L.); \\ Tel.: +55-21-3938-6646 (L.M.-P.); +55-21-3938-6646 (L.F.-d.-L.) \\ + Both authors contributed equally to this work.
}

Received: 9 March 2020; Accepted: 3 April 2020; Published: 8 April 2020

\begin{abstract}
Background: Piperine, an amide extracted from the Piper spices, exhibits strong anti-tumor properties. However, its effect on the epithelial-mesenchymal transition (EMT) process has never been investigated. Herein, we evaluate the toxic effect of piperine on lung adenocarcinoma (A549), breast adenocarcinoma (MDA-MB-231) and hepatocellular carcinoma (HepG2) cell lines, as well as its ability to inhibit EMT-related events induced by TGF- $\beta 1$ treatment. Methods: The cell viability was investigated by MTT assay. Protein expression was evaluated by Western blot. Gene expression was monitored by real-time PCR. Zymography assay was employed to detect metalloproteinase (MMP) activity in conditioned media. Cell motility was assessed by the wound-healing and phagokinetic gold sol assays. Results: The results revealed that piperine was cytotoxic in concentrations over $100 \mu \mathrm{M}$, showing IC50 values for HepG2, MDA-MB-231 and A549 cell lines of 214, 238 and $198 \mu \mathrm{M}$, respectively. In order to investigate whether piperine would reverse the TGF- $\beta 1$ induced-EMT, the A549 cell line was pretreated with sublethal concentrations of the natural amide followed by the addition of TGF- $\beta 1$. Besides disrupting EMT-related events, piperine also inhibited both ERK $1 / 2$ and SMAD 2 phosphorylation. Conclusions: These results suggest that piperine might be further used in therapeutic strategies for metastatic cancer and EMT-related disorders.
\end{abstract}

Keywords: piperine; cancer; piperidinyl amide; epithelial-mesenchymal transition; ERK1/2; SMAD

\section{Introduction}

The discovery of new cancer drugs is a hot topic in cancer research. Over the last twenty years, numerous studies have shown that many natural products display chemoprotective properties against 
different types of cancers [1,2]. In this context, piperine (a trans-trans isomer of 1-piperoyl piperidine) (Figure 1), the pungent amide present in Piper spices, such as the widely used black pepper (Piper nigrum L.,) is known to present a broad spectrum of biological activities, including its anti-cancer effect [3-5].

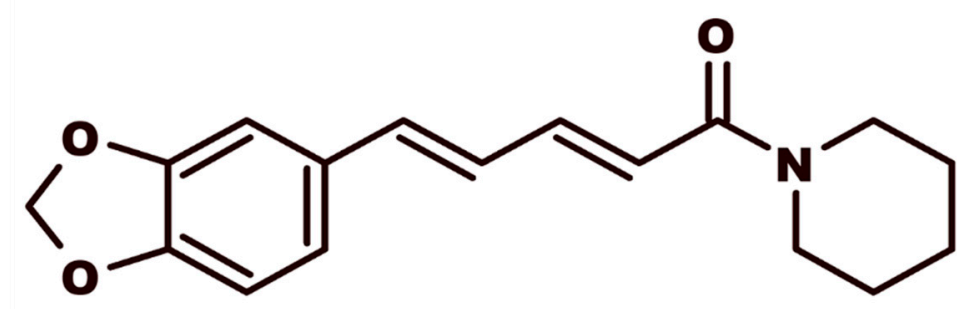

Figure 1. Chemical structure of piperine \{1-[5-(1,3-benzodioxol-5-yl)-oxo2,4-pentadienyl]piperidine $\}$.

Regarding the multidrug resistance (MDR) phenotype, a serious obstacle for the treatment of cancer patients [6], previous studies have demonstrated that piperine inhibits the activity of the main ABC transporters related to MDR phenotype [7,8]. Since piperine has been used as a bioavailability enhancer, it also has an effect over major drug-metabolizing enzyme CYP3A4 [9,10]. Piperine mitigates liver damage prompted by renal ischemia-reperfusion [11] and ameliorates oxidative stress [12,13]. Piperine also has antipyretic [14], analgesic [15], anti-parasitic [16,17] and anti-inflammatory [15,18,19] activities. The anti-tumoral properties are particularly noteworthy because of the current interest in identifying useful natural products for cancer treatment.

Several papers have demonstrated that piperine is cytotoxic for different types of human and mouse cancer cells, including both human aggressive triple negative cell lines MDA-MB-468 and MDA-MB-231, as well as the murine cell line, 4T1 [20-25], all of which have found extensive use as in the study of molecular mechanisms related to breast cancer metastasis [26,27]. Selvediran and colleagues [28] showed that benzo $(\alpha)$ pyrene-induced lung carcinogenesis in mice is prevented by the oral administration of piperine. In addition, piperine-treated mice showed a decrease in lung metastasis induced by mouse mammary carcinoma and melanoma cells [25,28]. Angiogenesis was also repressed by piperine [29], which may contribute to and/or explain its anti-metastatic effect. Recent findings have demonstrated that piperine modulates cancer cell motility [22], as well as the expression and/or activity of metalloproteinases (MMPs) [30]. In addition, it has been shown that piperine is able to inhibit breast cancer stem cell renewal and Wnt signaling [31]. Hwang and colleagues [32] demonstrated that piperine strongly repressed the PMA-induced phosphorylation of the extracellular-signal-regulated kinase 1/2 (ERK1/2) in human cancer cells. More recently, it has been demonstrated that piperine treatment repressed the expression of $\alpha$-smooth muscle actin $(\alpha$-SMA), fibronectin (FN) and collagen in the pancreas and pancreatic stellate cells [18]. Furthermore, piperine inhibited the production of TGF- $\beta$ in the pancreas and pancreatic stellate cells, as well as TGF- $\beta$-induced pSMAD 2/3 activation, suggesting that the natural amide ameliorates pancreatic fibrosis by inhibiting the TGF- $\beta /$ SMAD 2/3 signaling pathway during chronic pancreatitis [18]. All those events are deeply associated with the epithelial-mesenchymal transition (EMT) process [33-36], a biological phenomenon that occurs throughout the development of fibrosis, wound-healing, tumor progression, as well as in the emergence of chemotherapy-resistant cancer cells [37,38]. EMT activation can be induced by different growth factors, such as TGF- $\beta 1$, insulin-like growth factors (IGFs) and epidermal growth factors (EGF), among others $[39,40]$. Over the last ten years, TGF- $\beta 1$ has been described as a potent EMT inducer [41]. Its role in modulating the activation of both canonical (SMAD-dependent) and noncanonical (SMAD-independent) signaling pathways is well described [42]. Since the activation of these signaling pathways is closely associated with the acquisition of a more invasive phenotype by tumor cells, the identification and/or inhibition of molecular targets associated with them is essential to fight the progression of metastatic diseases [43]. 
The anti-metastatic effect of piperine was first described in a murine model of lung metastasis using the B16-F10 cell line [44]. Further, Lai et al. [25] confirmed this effect in a murine breast cancer model. However, the molecular mechanism responsible for the anti-metastatic property of piperine is still unknown.

Several groups have already studied the cytotoxic effects of piperine, as well as its ability to overcome the MDR phenotype, a multifactorial phenomenon linked to EMT process [45-49]. Given the evidence, it is plausible to infer that piperine may be further used as a prototype molecule for the development of new derivatives with strong anti-carcinogenic effects. Over the last five years, it has been demonstrated that EMT model represents an interesting approach to the study of the anti-carcinogenic effects of natural compounds [50,51]. Although piperine is able to inhibit the events associated with cancer development and/or progression [21,22,30], its role in EMT is still unrecognized.

\section{Materials and Methods}

The antibodies against N-cadherin (N-cad; cat. number sc-59987; dilution 1:1000), Fibronectin (FN; cat. number sc-8422; dilution 1:2000), total SMAD 2 (cat. number sc-393312; dilution 1:500), p-ERK1/2 (cat. number sc-81492; dilution 1:500), total ERK1/2 (cat. number sc-514302; dilution 1:1000), MMP2 (cat. number sc-13594; dilution 1:1000), MMP-9 (cat. number sc-21733; dilution 1:1000) and Glyceraldehyde 3-phosphate dehydrogenase (GAPDH, cat. number sc-32233; dilution 1:5000) were purchased from Santa Cruz Biotechnology (Santa Cruz, CA, USA). Human TGF- $\beta 11$ was purchased from R\&D Systems (Minneapolis, MN, USA). Antibody against p-SMAD 2 (cat. number 3108; dilution 1:500) was purchased from Cell Signaling (Danvers, MA, USA). TGF- $\beta$ receptor I (TGF- $\beta$ 1RI; cat. number ab31013, dilution 1:1000) and TGF- $\beta$ receptor II (TGF- $\beta$ 1RII, cat. number ab61213, dilution 1:1000) were purchased from Abcam (Cambridge, MA, USA). Secondary antibodies HRP-conjugated anti-mouse IgG (cat. number AP308P, dilution 1:5000) or HRP-conjugated anti-rabbit IgG (cat. number AP307P, dilution 1:5000) were purchased from Millipore (Burlington, MA, USA). Protease inhibitor (cat. number P8340), Coomassie Brilliant Blue R (cat. number B0149) and DMSO (cat. number 276855) were acquired from Sigma Aldrich (St. Louis, MO, USA). The ECL chemiluminescence kit (cat. number RPN2108) was purchased from GE healthcare (Little Chalfont, Buckinghamshire, UK). PCR primers were purchased from Life Technologies (São Paulo, SP, Brazil). The alkaloid was diluted in dimethyl sulfoxide (DMSO), and $0.5 \%$, which is not toxic to human cell line cultures [52], and this was the highest final concentration of DMSO used in the biological assays.

\subsection{Isolation of Natural Piperine}

Natural piperine used in this work was isolated from dry P. nigrum fruits, as previously described [51-53]. The amide was fully characterized through ${ }^{1} \mathrm{H}$ and ${ }^{13} \mathrm{C}$ nuclear magnetic resonance (NMR) spectra (Supplementary Figures S1-S3). The purity grade of isolated piperine was determined as $\geq 98 \%$ by reversed-phase high performance liquid chromatography (RP-HPLC) (Supplementary Figure S4).

The ${ }^{1} \mathrm{H}$ and ${ }^{13} \mathrm{C}$ nuclear magnetic resonance (NMR) spectra were recorded in a Bruker Ultrashield Plus Spectrometer (BrukerBioSpin $\mathrm{GmbH}$, Rheinstetten, Germany) operating at $500 \mathrm{MHz}$ for ${ }^{1} \mathrm{H}$ and $125 \mathrm{MHz}$ for ${ }^{13} \mathrm{C} .{ }^{1} \mathrm{H}$ and ${ }^{13} \mathrm{C}$ NMR shifts $(\delta)$ are reported in parts per million (ppm) with respect to $\mathrm{CDCl} 3(\delta 7.29 \mathrm{ppm}$ for $1 \mathrm{H}$; and $\delta 77.0 \mathrm{ppm}$ for $13 \mathrm{C}$ ). Thin layer chromatography analysis was performed on silica gel pre-coated TLC Aluminum sheets, comparing with authentic samples and the spots were visualized under UV light at 254 or $356 \mathrm{~nm}$ ). Reversed phase high performance liquid chromatography (RP-HPLC) was performed in a Shimadzu chromatograph consisting of two LC-20AT series pumps, SPD-M20A series diode array detector, and Rheodyne 7125i injector with $20 \mu \mathrm{L}$ loop. Equipment control and data acquisition were realized using the LCSolution software (software version 1.21, Shimadzu, Kioto, Japan). Analyses were performed in a C-18 reverse phase analytical column of $150 \times 4.6 \mathrm{~mm}, 5 \mathrm{~mm}$ of particle (Allure Restek, Bellefonte, PA, USA), maintained at $30^{\circ} \mathrm{C}$. The mobile 
phase used was a mixture of acetonitrile $(98 \%$, solvent $\mathrm{B})$ and water $(2 \%$, solvent $\mathrm{A})$. The injection volume was $20 \mu \mathrm{L}$ and the separation was performed in isocratic mode (constant flow of $1.2 \mathrm{~mL} \cdot \mathrm{min}^{-1}$ ).

\subsection{Cell Lines and Cell Culture}

The human cancer cell lines used in this study were: (i) lung adenocarcinoma (A549), (ii) mammary adenocarcinoma (MDA-MB-231) and (iii) hepatocellular carcinoma (HepG2). All cell lines were obtained from the American Type Culture Collection (Manassas, VA, USA), and cultured in DMEM (Gibco, Grand Island, NY, USA) supplemented with $10 \%$ fetal bovine serum (FBS; Life Technologies, Inc., Rockville, MD, USA) and $100 \mathrm{U} / \mathrm{mL}$ penicillin, $100 \mu \mathrm{g} / \mathrm{mL}$ streptomycin (Life Technologies, Inc., Rockville, MD, USA). Cells were kept at $37{ }^{\circ} \mathrm{C}$ with $5 \% \mathrm{CO}_{2}$ in a humidified atmosphere.

\subsection{MTT Assay}

The effects of piperine on the cell viability was evaluated through the 3-(4,5-dimethylthizol-2-yl)-2,5-diphenyltetrazolium bromide (MTT) assay as previously described [53]. Briefly, the cell lines were seeded onto a 96-well plate at a concentration of $4.0 \times 10^{3}$ cells/well. After 18 $\mathrm{h}$, the medium was renewed, and the cells were treated with increasing concentrations of piperine (20, $40,80,160,320 \mu \mathrm{M})$ for the next $72 \mathrm{~h}$. At the end of the exposure period, the cells were incubated with $20 \mu \mathrm{L}$ of MTT solution ( $5 \mathrm{mg} / \mathrm{mL}$ ) (Sigma Chemical Co., St. Louis, MO, USA) for $4 \mathrm{~h}$ at $37^{\circ} \mathrm{C}$. After the medium was removed, $100 \mu \mathrm{L}$ of DMSO was added to each well, and the absorbance was measured with a plate reader (Model AD340, Beckman Coulter, Brea, CA, USA) at a wavelength of $570 \mathrm{~nm}$. The cell viability index was calculated using the following formula: experimental optical density value/control OD value. Each experiment was repeated three times.

\subsection{Cell Treatment for EMT Analysis}

A549 cells $\left(4 \times 10^{5}\right.$ cells per well) were plated in 6-well plates. After $18 \mathrm{~h}$, the medium was changed, and the cell monolayers were pre-treated or not with increasing concentrations of piperine $(20,40,80 \mu \mathrm{M})$ for $24 \mathrm{~h}$. After pretreatment, the cells were stimulated or not with $1 \mathrm{ng} / \mathrm{mL}$ TGF- $\beta 1$, and the cell cultures incubated for the next $48 \mathrm{~h}$ at $37{ }^{\circ} \mathrm{C}$ with $5 \% \mathrm{CO}_{2}$ in a humidified atmosphere.

\subsection{Immunoblotting Assay}

A549 cells were plated and treated or not with piperine and TGF- $\beta 1$, as described in Section 2.4 of the Materials and Methods. After treatment, the cells were scrapped and lysed in RIPA buffer (50 mM Tris- $\mathrm{HCl}$ pH 7.4; 0.5\% NP-40; $250 \mathrm{mM} \mathrm{NaCl} ; 5 \mathrm{mM}$ EDTA and $50 \mathrm{mM} \mathrm{NaF}$ ) containing freshly added protease inhibitor solution [54]. Protein content was determined by using a microBCA protein assay reagent kit (Pierce), with BSA as standard. Aliquots (30 $\mu \mathrm{g}$ of protein per lane) were subjected to SDS/PAGE and transferred to nitrocellulose membranes. Blocking was performed overnight with Tris-buffered saline with $0.1 \%(\mathrm{v} / \mathrm{v})$ Tween 20 (TBS-T) containing 5\% (w/v) nonfat dry milk. The membranes were incubated with primary antibodies for $2 \mathrm{~h}$ at room temperature and, after several washes with TBS-T, incubated for one more hour with the appropriate secondary antibody and then developed using an ECL chemiluminescence kit (GE Healthcare, USA). ImageJ software was used for densitometry analysis of immunoblots, and all measurements were normalized against GAPDH loading controls [55].

\subsection{Cell Morphology and Circularity Analysis}

A549 cells were plated and treated or not with piperine and TGF- $\beta 1$ as described before. After treatment, photomicrography was taken by phase-contrast microscopy (Nikon) at $80 \times$ magnification. Circularity ratio $(C)$ was calculated as $\mathrm{C}=\mathrm{P} /(\mathbf{4} \pi \mathrm{A})^{0.5}$, where $\mathrm{P}$ and $\mathrm{A}$ are, respectively, the perimeter and area of the cell [56]. 


\subsection{Cell Motility Assay}

Cell motility was assessed by the wound-healing and phagokinetic gold sol assays as previously described [57]. For phagokinetic gold sol assay, cells were plated and treated or not with piperine and TGF- $\beta 1$ as mentioned. After treatment, cells were detached, and $5.0 \times 10^{2}$ cells were plated onto gold sol-coated well and incubated for $18 \mathrm{~h}$. Photographs were taken by phase-contrast microscopy (Nikon) at $80 \times$ magnification; the track area of 200 cells was measured by using the Scion Image program, and expressed as squared pixels. For the wound-healing assay, cells were treated as above and scratches were made on the cell monolayers with plastic pipette tips by moving them perpendicularly to the lines marked at the bottom of wells. The cells were then rinsed and incubated in culture medium for $18 \mathrm{~h}$. Pictures were taken at $0 \mathrm{~h}$ and $18 \mathrm{~h}$. The procedure was based on previous studies $[57,58]$.

\subsection{Zymography}

For gelatinase activity, cell culture supernatants were used as previously described [55]. In brief, samples were subjected to SDS/PAGE, using $1.5 \mu \mathrm{g} \cdot \mathrm{mL}^{-1}$ gelatin type A from porcine skin (Sigma). The gels were renatured, developed in $50 \mathrm{mM}$ Tris, $2.5 \mathrm{mM} \mathrm{CaCl}, \mathrm{pH} 7.5$, overnight at $37^{\circ} \mathrm{C}$, stained with Coomassie Brilliant Blue $\mathrm{R}$, and then destained until the bands became clear.

\subsection{Determination of mRNA Levels by Real-Time Quantitative PCR ( $q$ RT-PCR)}

The number of transcript copies was monitored by qRT-PCR analysis as previously described [56]. In brief, A549 cells were plated and treated or not with piperine and TGF- $\beta 1$ as described before, and the total RNA of cells was extracted and purified using Qiagen RNeasy Mini Kit (Qiagen, Germantown, MD, USA). The cDNA was prepared from $2 \mu \mathrm{g}$ of total RNA using a RevertAid First Strand cDNA Synthesis Kit (Thermo Fisher, Bartlesville, OK, USA) with oligo-dT primer, according to manufacturer's instructions. qRT-PCR was performed using SYBRGreen QRT-PCR Kit plus ROX (LGC Biotecnologia, São Paulo, SP, Brazil) according to the manufacturer's protocols. The following primer pairs were used: E-cadherin (E-cad): (sense, 5' -CGGGAATGCAGTTGAGGATC - ${ }^{\prime}$; antisense, 5'-AGGATGGTGTAAGCGATGG-3'), N-cad: (sense, $5^{\prime}$-CTCCTATGAGTGGAACAGGAACG -3'; antisense, 5'-TTGGATCAATGTCATAATCAAGTGCTGTA-3'), FN: (sense, 5'-TTATGACGACGGGAAGAC - $3^{\prime}$; antisense, 5'-GCTGGATGGAAAGATTAC $-3^{\prime}$ ) and GAPDH: (sense, 5'-TGACTTCAACAGCGACACCCA-3'; antisense, 5'-GCCAAATTCGTTGTCATAC-3'). Amplification was carried out as previously described in Alisson-Silva et al. [56].

\subsection{Statistical Analysis}

Statistical analyses were performed using the software GraphPad Prism (Software version 7, San Diego, CA, USA). Each experiment was repeated at least three times. Data were expressed as means \pm SD and were analyzed using one-way ANOVA with a Bonferroni posttest for a comparison of the differences. Values of $p \leq 0.05$ were accepted as statistically significant.

\section{Results}

\subsection{Piperine Inhibits Proliferation of Human Cancer Cell Lines}

Before assessing the effect of piperine on cancer cells undergoing EMT, a cell viability assay was performed to determine the $\mathrm{IC}_{50}$ and select nonlethal concentrations of the natural amide for further analysis. For this purpose, cells were treated with increasing concentrations $(20-320 \mu \mathrm{M})$ of piperine for $72 \mathrm{~h}$. The cell viability monitored by the MTT assay, showed that 160 and $320 \mu \mathrm{M}$ of piperine were toxic for all cell lines utilized. The $\mathrm{IC}_{50}$ values for HepG2, MDA-MB-231 and A549 cells were $214 \mu \mathrm{M}$ (Figure 2A), $238 \mu \mathrm{M}$ (Figure 2B) and $198 \mu \mathrm{M}$ (Figure 2C), respectively. Because there were no significant differences in cell viability when the concentrations of the amide were below $80 \mu \mathrm{M}$ (Figure 2A-C), three concentrations of piperine ranging from 20 to $80 \mu \mathrm{M}$ were selected for the following experiments. 

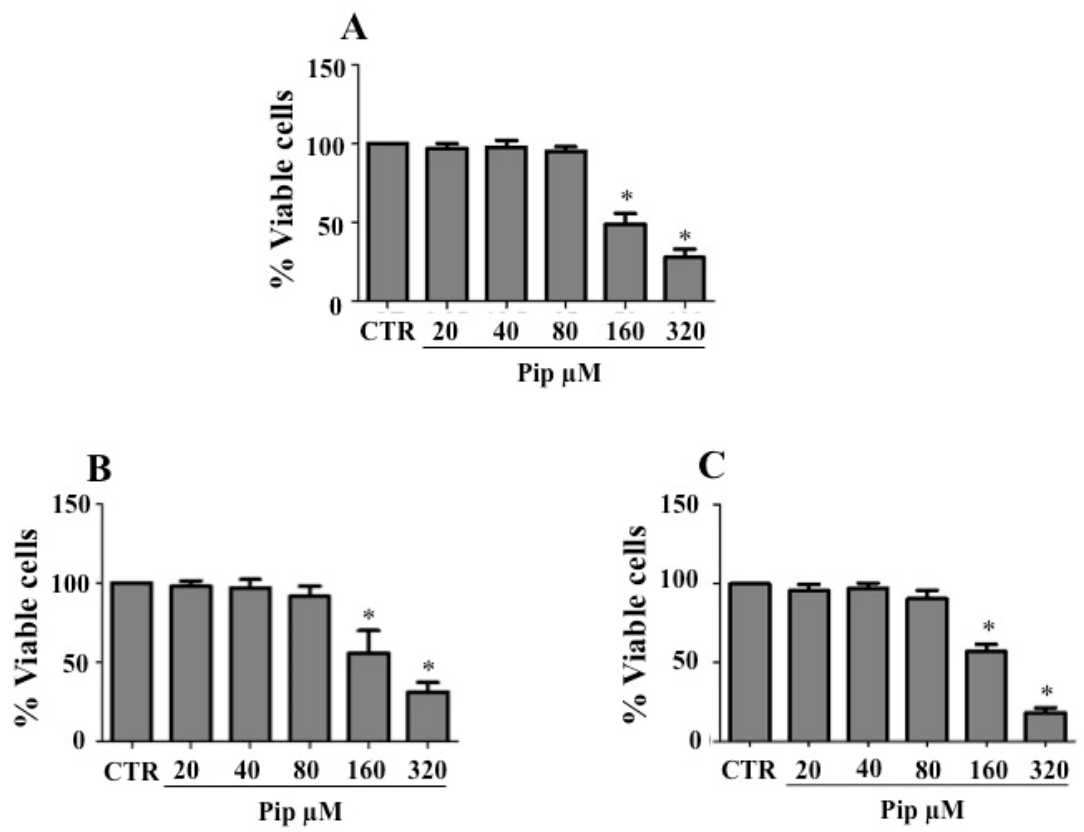

Figure 2. Inhibition of growth by piperine in lung adenocarcinoma (A549), breast adenocarcinoma (MDA-MB-231) and hepatocellular carcinoma (HepG2) cells. (A) HepG2, (B) MDA-MB-231 and (C) A549 cells were treated or not (CTR) with 20,40,80,160 and $320 \mu \mathrm{M}$ piperine for $72 \mathrm{~h}$, and the cell viability was monitored by MTT assay at $570 \mathrm{~nm}$ using a Beckman Coulter AD 340 plate-reading spectrophotometer. The following formula has been used to calculate the percentage of viable cells: (viable cells) $\%=(\mathrm{OD}$ of drug-treated sample/OD of untreated sample $) \times 100$. Data are representative of three independent experiments \pm SD. ${ }^{*} p \leq 0.05$ vs. untreated cells (CTR).

\subsection{Piperine Supresses Morphological and Phenotypical Changes Induced by TGF- $\beta 1$}

To analyze the anti-EMT effect of piperine, we used the A549 cell line, since it has been approved in vitro as an interesting model for monitoring EMT-related events [59]. As expected, when $1 \mathrm{ng} / \mathrm{mL}$ TGF- $\beta 1$ was added to cell culture, cells lost cell-cell adhesion and changed from a compact epithelial morphology to a spindle-shaped cell morphology (Figure 3A). After TGF- $\beta 1$ treatment, the cell circularity ratios were significantly reduced when compared with control epithelial cells, which morphologically resemble a circle, presenting circularity ratios approaching one (Figure 3B). However, when cells were incubated with sublethal concentrations of the alkaloid, especially 40 and $80 \mu \mathrm{M}$, prior to TGF- $\beta 1$ treatment, such changes were significantly suppressed (Figure 3A). In this condition, the cell circularity was similar to control cells (Figure 3B).
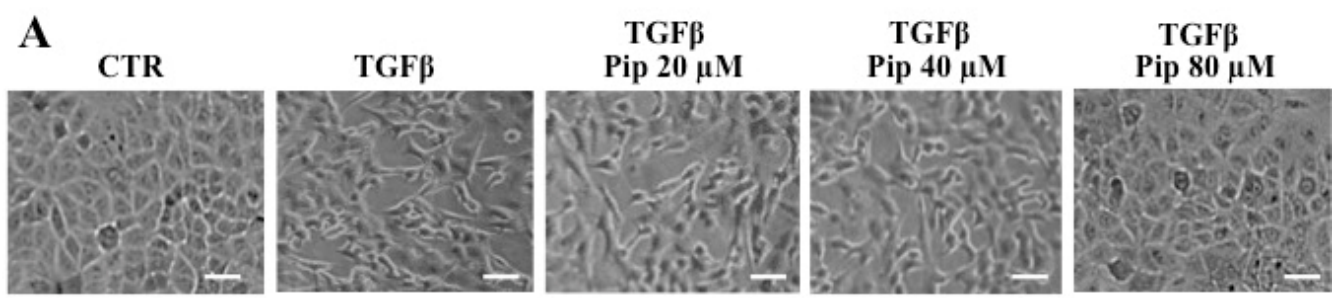

Figure 3. Cont. 


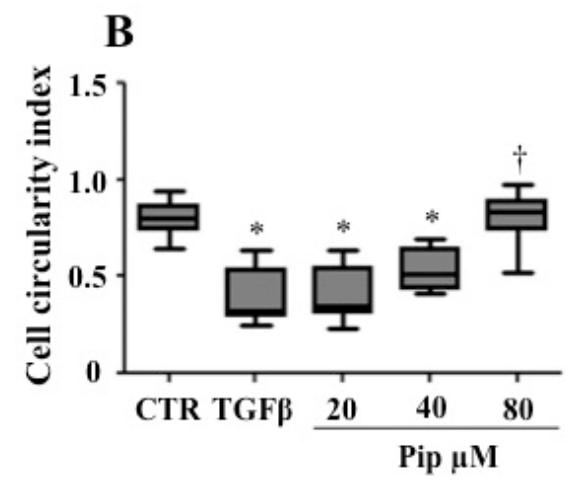

Figure 3. Pretreatment with piperine modulates TGF- $\beta 1$-induced morphological changes in A549 cells. (A) A549 cells were pretreated with non-cytotoxic doses of piperine (20, 40 and $80 \mu \mathrm{M})$ for $24 \mathrm{~h}$ followed by treatment with $1 \mathrm{ng} / \mathrm{mL}$ TGF- $\beta 1$ for $48 \mathrm{~h}$, then followed by the observation under phase-contrast microscopy, scale bar $=100 \mu \mathrm{M}$. (B) After TGF- $\beta 1$ treatment, cells acquired spindle-shaped morphology. Pretreatment with piperine 40 and $80 \mu \mathrm{M}$ attenuated or suppressed such event, respectively. Data are representative of 500 cells from three independent experiments $\pm \mathrm{SD}$. ${ }^{*} p \leq 0.05$ vs. untreated cells (CTR); $+p \leq 0.05$ vs. TGF- $\beta$.

The ability of piperine in modulating the cell phenotype induced by TGF- $\beta 1$ was first evaluated by Western blot analysis (Figure 4). In response to TGF- $\beta 1$, the expression of the mesenchymal markers FN and N-cad was significantly increased. However, when cells where pretreated with 40 and $80 \mu \mathrm{M}$ of piperine, such events where abrogated (Figure $4 \mathrm{~A}-\mathrm{C}$ ). qPCR results corroborated Western blot data, since the ability of TGF- $\beta 1$ to up-regulate the mRNA levels for FN (Figure 4D) and N-cad (Figure 4E) were significantly repressed by piperine $80 \mu \mathrm{M}$ (Figure 4D,E). As expected, mRNA levels for epithelial marker E-cad were considerably reduced by TGF- $\beta 1$. However, such an event was attenuated by pretreatment with piperine $80 \mu \mathrm{M}$ (Figure $4 \mathrm{~F}$ ).
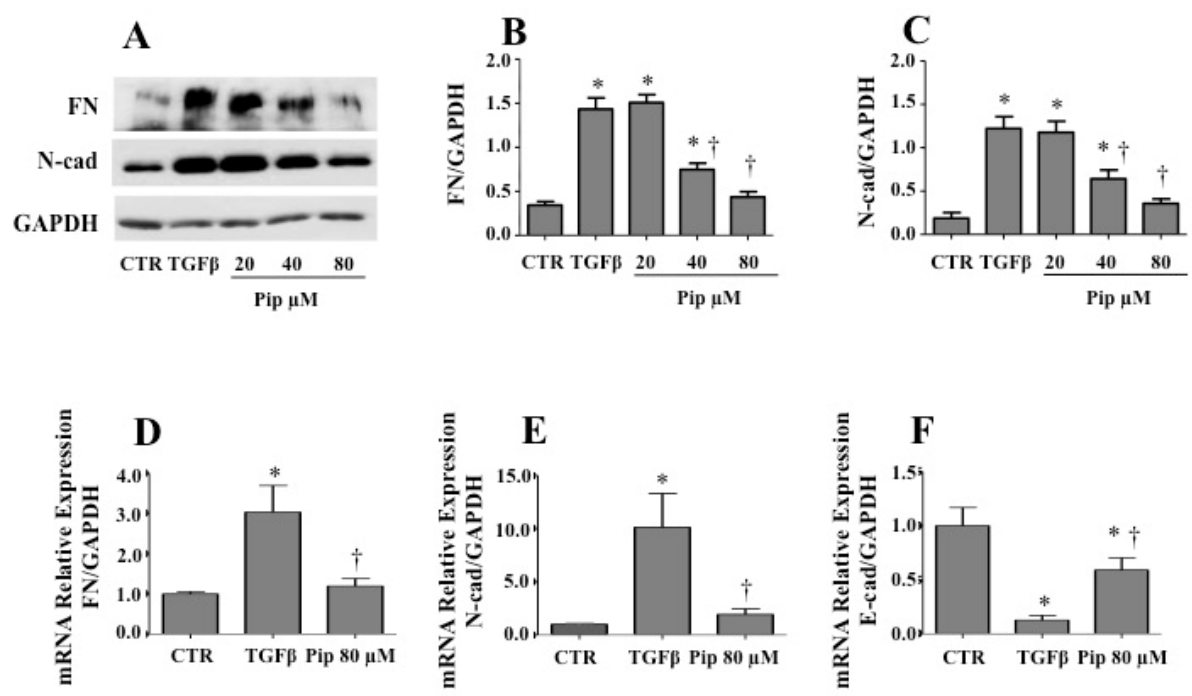

Figure 4. Pretreatment with piperine attenuates TGF- $\beta 1$-induced mesenchymal-like phenotype in A549 cells. A549 cells were pretreated with non-cytotoxic doses of piperine $(20,40$ and $80 \mu \mathrm{M})$ for $24 \mathrm{~h}$, followed by treatment with $1 \mathrm{ng} / \mathrm{mL}$ TGF- $\beta 1$ for $48 \mathrm{~h}$. After treatment, cells were used for Western blot and qPCR analysis. (A) Western blot analysis of the expression of mesenchymal markers fibronectin (B) and N-cad (C). GAPDH was used as loading control. Densitometry was performed using the image-processing program ImageJ. The relative copy number of transcripts for fibronectin (D), N-cad (E) and E-cad (F) was determined by qRT-PCR to evaluate changes in gene expression. The results are representative of three independent experiments. The results are shown as mean $\pm \mathrm{SD} .{ }^{*} p \leq 0.05$ vs. untreated cells (CTR); $+p \leq 0.05$ vs. TGF- $\beta$. 


\subsection{Piperine Inhibits A549 Cell Migration and MMP-2 Secretion Induced by TGF- $\beta 1$}

Since the acquisition of a spindle-shaped morphology and reduced intercellular adhesion is a fundamental requirement for cell motility, we next examined the effect of piperine on the TGF- $\beta 1$-induced migration of A549 cells. As expected, the phagokinetic gold sol (Figure 5A,B) and wound-healing (Figure 5C,D) assays revealed that TGF- $\beta 1$ enhanced the cell motility when compared to the control cells, whereas pretreatment with 40 and $80 \mu \mathrm{M}$ piperine inhibited the TGF- $\beta 1$-induced cell migration.
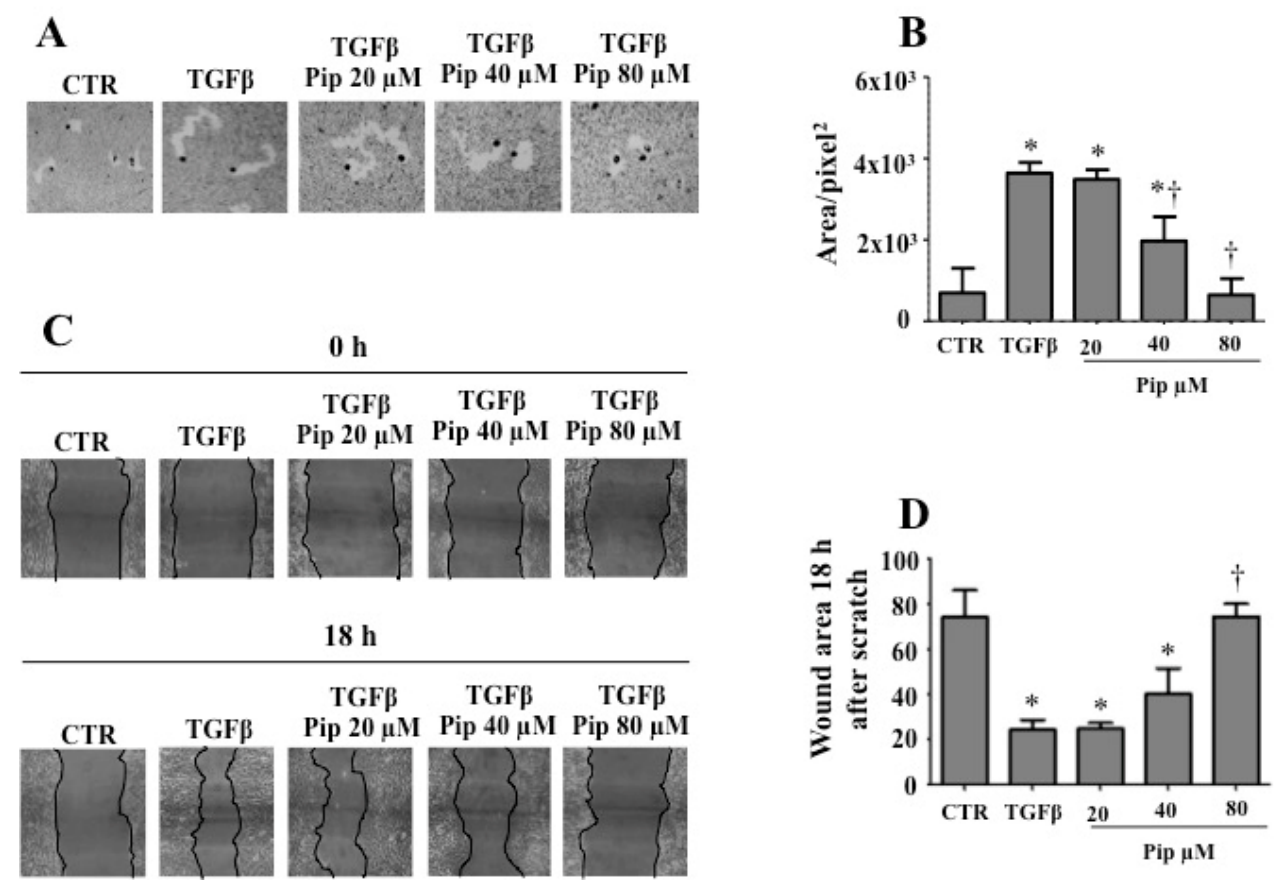

Figure 5. Pretreatment with piperine inhibits the cell motility of A549 cells treated with TGF- $\beta 1$. To analyze the cell motility, A549 cells were pretreated with non-cytotoxic doses of piperine (20, 40 and $80 \mu \mathrm{M}$ ) for $24 \mathrm{~h}$, followed by treatment with $1 \mathrm{ng} / \mathrm{mL}$ TGF- $\beta 1$ for $48 \mathrm{~h}$. After treatments, the cell motility was evaluated based on phagokinetic motility $(\mathbf{A}, \mathbf{B})$ and wound assay $(\mathbf{C}, \mathbf{D})$. For phagokinetic motility, track area of 200 cells was monitored with the aid of the program Scion Image and expressed as squared pixels. For wound assay, photos were taken before and after incubation. The results are representative of four independent experiments. Quantitative analyses are shown as mean $\pm \mathrm{SD}$. ${ }^{*} p \leq 0.05$ vs. untreated cells (CTR), $+p \leq 0.05$ vs. TGF- $\beta$.

Furthermore, we used gelatin zymography (Figure 6A) and Western blot (Figure 6B-D) analysis to examine the inhibitory effect of the natural amide on MMP-2 and MMP-9 activities. When compared to the control, TGF- $\beta 1$-treated cells presented an elevated activity (Figure 6A) and expression (Figure 6B,C) for MMP-2. Interestingly, treatment with 40 and $80 \mu \mathrm{M}$ piperine, prior to TGF- $\beta 1$ addition, was able to suppress such phenomena (Figure 6A-C). The inhibitory effect seems to be specific for MMP-2, since no concentration of the alkaloid was able to compromise the basal MMP-9 activity and expression (Figure 6A,B,D). These results suggest that piperine prevents the acquisition of an invasive phenotype, as well as the migration of A549 cells at non-toxic concentrations. 
A

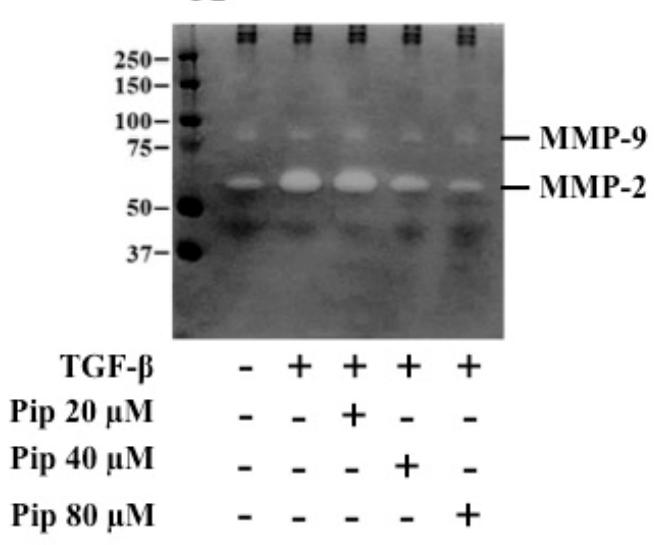

C

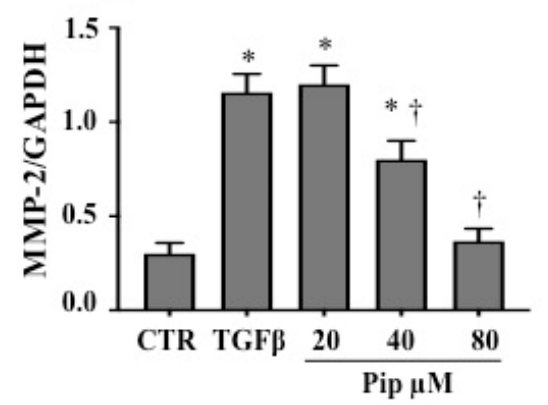

B

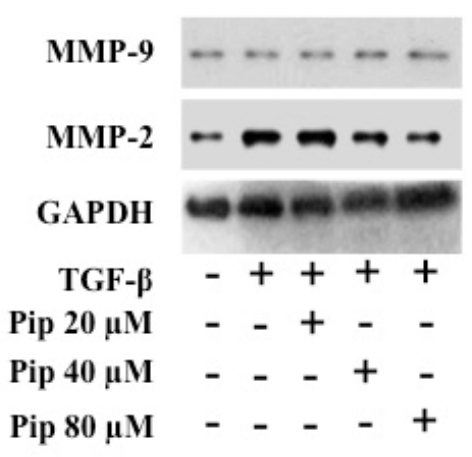

Figure 6. Pretreatment with piperine inhibits MMP-2 activity and expression in A549 cells treated with TGF- $\beta 1$. A549 cells were pretreated with non-cytotoxic doses of piperine $(20,40$ and $80 \mu \mathrm{M})$ for $24 \mathrm{~h}$, followed by treatment with $1 \mathrm{ng} / \mathrm{mL}$ TGF- $\beta 1$ for $48 \mathrm{~h}$. (A) After treatments, gelatin zymography was employed to detect MMP activity. (B) Western blot analysis to investigate the expression of MMP-2 (C) and MMP-9 (D) was performed by using the cell culture medium. The maximum volume of supernatant used to analyze the activity and expression of MMPs was $30 \mu \mathrm{L}$. The volume of each experimental point was adjusted based on the amount of protein in the cell lysates. The results are representative of three independent experiments. Quantitative Western blot analyses are shown as mean \pm SD. ${ }^{*} p \leq 0.05$ vs. untreated cells (CTR), $+p \leq 0.05$ vs. TGF- $\beta$.

\subsection{Piperine Inhibits TGF- $\beta 1$-Induced Activation of ERK and SMAD Signaling Pathways}

Usually, the effect of TGF- $\beta 1$ on SMAD proteins does not vary in most cell types and is named the canonical TGF- $\beta$ pathway. In addition to activating SMADS, TGF- $\beta 1$ also modulates the activation of numerous cell-signaling pathways [60,61]. Unlike the canonical pathway, the modulation of other signaling pathways by TGF- $\beta 1$ is usually dependent on the context and cell type and is known as the noncanonical TGF- $\beta$ signaling pathway [62]. It has been well documented that over the last ten years, the canonical TGF- $\beta 1$ signaling pathway governed the field of TGF- $\beta$ research. However, more recently, increasing attention has been paid to the noncanonical TGF- $\beta$ signaling, particularly in the context of EMT-related events $[63,64]$. In order to evaluate the signaling pathways activated during EMT induction by TGF- $\beta 1$, and the effect of piperine pretreatment on them, we performed Western blot assays for TGF- $\beta$ receptors, -SMAD2 and p-ERK 1/2. Pretreatment with piperine did not reduce the expression of either type I (TGF $\beta$ RI) or type II (TGF $\beta$ RII) TGF- $\beta$ receptors (Figure 7A). Since receptor expression was unchanged, we decided to test the downstream signaling pathways. As expected, TGF- $\beta 1$ was able to increase phosphorylation of both SMAD2 and ERK 1/2 when compared to the control condition (Figure 7B,C). However, pretreatment with 40 an $80 \mu \mathrm{M}$ piperine was able to downregulate the phosphorylation of both SMAD-2 (Figure 7B) and ERK1/2 (Figure 7C), which may explain its anti-EMT effect. 

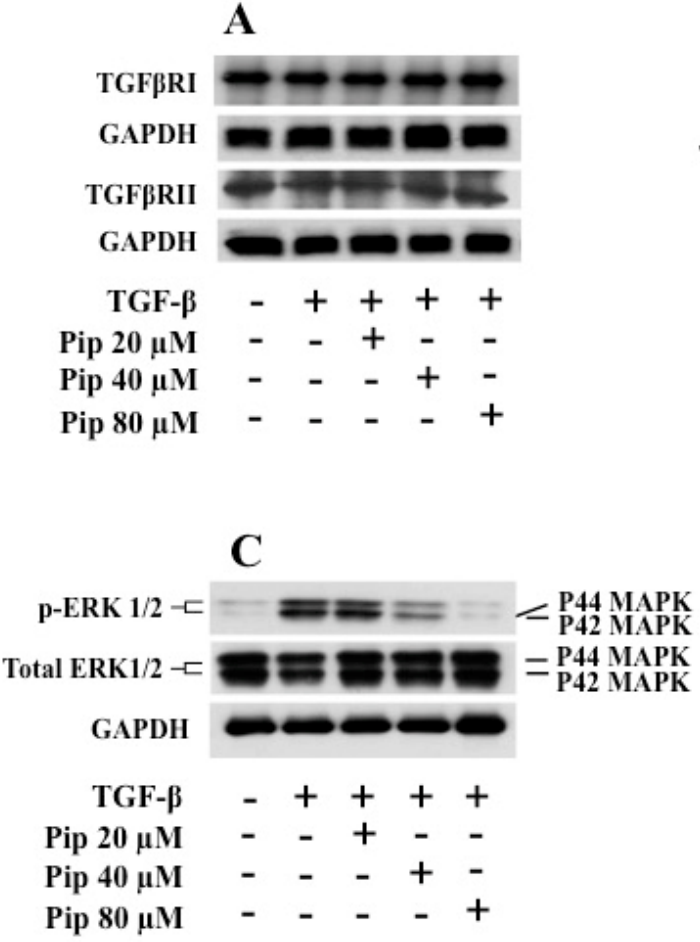

Figure 7. Effect of piperine on TGF- $\beta$ receptors (TGF $\beta$ RI and TGF $\beta$ RII) and ERK $1 / 2$ and SMAD2 activation in A549 cells treated with TGF- $\beta 1$. A549 cells were plated in serum free medium and pretreated with 20,40 and $80 \mu \mathrm{M}$ piperine for $24 \mathrm{~h}$. After treatment, cells were or not stimulated with $1 \mathrm{ng} / \mathrm{mL}$ recombinant human TGF $\beta 1$. The cells were then collected, washed with PBS and lysed in RIPA buffer. Western blot analysis was employed to evaluate (A) the expression of TGF $\beta$ RI and TGF $\beta$ RII receptors, (B) phospho-SMAD2 and (C) phospho-p44/42 MAPK (ERK1/2).

\section{Discussion}

Metastatic disease is the cause of over $90 \%$ of cancer-induced mortalities, which might be explained by the lack of effective treatments. For this reason, the concept that plant-derived natural products represent a key source of bioactive compounds remains a major challenge for both clinicians and scientists [65]. Metastasis can be divided into several stages. Among these, there is the improvement of migratory propriety, which can be attained through EMT [66,67]. TGF- $\beta 1$-induced EMT in A549 cells is a widely used model to study pulmonary fibrosis and lung cancer [59]. Our results corroborate previous studies, which have shown that TGF- $\beta 1$ induces A549 cells to lose their epithelial characteristics and to acquire a spindle-like appearance [68-70].

The anti-tumoral effect of piperine was described over fifteen years ago [44]. Since then, several studies have shown that the natural amide present potential as an anti-cancer agent, as it inhibits several aspects related to cancer progression and metastasis [71-73]. The EMT process is characterized by morphological, phenotypic and biochemical alterations, which together influence the behavior of tumor cells of epithelial origin [74]. In the literature, many studies have shown that piperine modulates crucial events related to EMT process, such as cell motility [22], MMP expression and activity [30], expression of mesenchymal proteins [18], as well as the activation of MAPK and SMAD signaling pathways [18,75]. However, so far, no study has demonstrated the ability of piperine to collectively compromise all of these events in cancer cells undergoing EMT.

Herein, we confirm that piperine presents potential as an anti-cancer agent, since it was able to significantly reduce the viability of cancer cells. We also observed that the administration of sublethal concentrations of piperine disrupted classical events related to TGF- $\beta 1$ induced-EMT processes, such as morphology changes, phenotypic alterations, increased cell motility and expression of metalloproteinases [66,76]. In order to monitor the effect of piperine on cell motility, we initially 
used the wound assay, a widely used technique [55,77-79]. The results showed that piperine abrogated the increased cell motility induced by TGF- $\beta 1$. However, since we did not use substances to block cell proliferation in this assay, the cell growth would mask the motility event. For this reason, we used another known technique, the phagokinetic gold sol assay, which has the advantage of measuring the motility of individual cells $[55,80]$. The results also demonstrated that piperine compromised the gain of migratory property by cancer cells.

Recently, Choi et al. [18] demonstrated that in a murine study of chronic pancreatitis, piperine attenuated the production of TGF- $\beta$ in the pancreas and improved the severity of fibrosis through inhibition of TGF- $\beta /$ SMAD signaling pathways. The authors also demonstrated that in TGF$\beta$-treated pancreatic stellate cells, piperine reduced the expression of the mesenchyml markers $\alpha \mathrm{SMA}$, FN and collagen. Likewise, we also observed that the expression of mesenchymal markers (FN and $\mathrm{N}$-cad) induced by TGF- $\beta 1$ was abrogated when A549 cells were pretreated with piperine.

In addition, we demonstrated that piperine inhibits both canonical and noncanonical TGF- $\beta$ signaling pathways in A549 cells undergoing EMT. Previous studies revealed that piperine obstructs NF-kB signal transduction cascade [81,82] and inhibits p38 [75,83], JNK [84] and ERK 1/2 [32,85] signaling pathways. Since both ERK and SMAD pathways might be activated by TGF- $\beta 1$, and modulate the EMT process [35,86-88], their inhibition may explain the anti-EMT effect of piperine. In 2011, Li and colleagues [7] described that piperine is able to re-sensitize multidrug resistant cancer cells. Recent studies support a close connection between EMT activation, the expression of ATP binding cassette (ABC) proteins and drug resistance [88-91]. Further studies need to be performed, but it is plausible to speculate that, somehow, the inhibition of the activity and/or expression of ABC transporters might enhance the anti-EMT effect of the natural amide.

\section{Conclusions}

Our study provides the first piece of evidence that piperine can attenuate EMT-related events induced by TGF- $\beta 1$ in the human alveolar adenocarcinoma A549 cells associated with inhibition of both canonical and noncanonical TGF- $\beta 1$ signaling pathways. More importantly, piperine also prevents the cell from acquiring greater migratory capacity, N-cad and FN expression and MMP-2 secretion. Given the gathered data, it is reasonable to speculate that piperine may show therapeutic potential against EMT-related disorders. The continued advancement of this line of research may open the door to an entirely new class of anti-cancer drugs.

Supplementary Materials: The following are available online at http://www.mdpi.com/2305-6320/7/4/19/s1, Figure S1: NMR ${ }^{1} \mathrm{H}$ spectrum $\left(500 \mathrm{MHz}, \mathrm{CDCl}_{3}\right)$ of natural piperine, Figure S2: NMR ${ }^{13} \mathrm{C}$ spectrum $(125 \mathrm{MHz}$, $\mathrm{CDCl}_{3}$ ) of natural piperine, Figure S3: NMR ${ }^{1} \mathrm{H}$ and ${ }^{13} \mathrm{C}$ data for natural piperine, Figure S4: HPLC-RP for piperine (Retention time: 5.6 min.; Purity grade $\geq 98 \%$ ).

Author Contributions: Conceptualization, L.F.-d.-L.; data curation, L.M.d.F., L.R.J.d.S., L.F.-d.-L. and L.M.-P.; formal analysis, L.M.d.F., L.R.J.d.S., T.N.F. and D.C.d.A.-P.; funding acquisition, C.G.F.d.L., A.M., M.E.F.d.L., J.O.P., L.M.-P. and L.F.-d.-L.; investigation, L.M.d.F., L.M.-P. and L.F.-d.-L.; methodology, L.M.d.F., L.R.J.d.S., M.A.R.d.C.S., V.d.S.C., K.M.d.C., J.S.d.R., J.d.N.S.-D., M.E.F.d.L., T.N.F. and D.C.d.A.-P.; project administration, L.M.-P. and L.F.-d.-L.; resources, J.O.P., M.E.F.d.L., C.G.F.d.L., L.M.-P. and L.F.-d.-L.; software, L.R.J.d.S., K.M.d.C., J.S.d.R., V.d.S.C.; supervision, M.E.F.d.L., L.M.-P. and L.F.-d.-L.; validation, L.M.d.F., L.R.J.d.S., J.d.N.S.-D., M.A.R.d.C.S., T.N.F. and D.C.d.A.-P.; writing—original draft, L.M.d.F., L.M.-P., L.F.-d.-L., M.E.F.d.L.; writing—review \& editing, C.G.F.-d.-L; A.M., J.O.P., L.M.-P. and L.F.-d.-L. All authors have read and agreed to the published version of the manuscript.

Funding: The authors are supported by grants from the Brazilian agencies: Coordenação de Aperfeiçoamento de Pessoal de Nível Superior (CAPES), Fundação Carlos Chagas Filho de Amparo à Pesquisa do Estado do Rio de Janeiro (FAPERJ), Conselho Nacional de Desenvolvimento Científico e Tecnológico (CNPq), and Cancer Foundation.

Acknowledgments: The authors would like to thank Lana Cristina dos Santos Valvano, Jose Avelino and Paulo Cesar Cordeiro da Silva for their helpful technical assistance.

Conflicts of Interest: The authors declare that the research was conducted in the absence of any commercial or financial relationships that could be construed as a potential conflict of interest. 


\section{References}

1. Park, E.J.; Pezzuto, J.M. Botanicals in cancer chemoprevention. Cancer Metastasis Rev. 2002, 21, $231-255$. [CrossRef] [PubMed]

2. Eichhorn, T.; Efferth, T. P-glycoprotein and its inhibition in tumors by phytochemicals derived from Chinese herbs. J. Ethnopharmacol. 2012, 141, 557-570. [CrossRef] [PubMed]

3. Smilkov, K.; Ackova, D.G.; Cvetkovski, A.; Ruskovska, T.; Vidovic, B.; Atalay, M. Piperine: Old Spice and New Nutraceutical? Curr. Pharm. Des. 2019, 25, 1729-1739. [CrossRef]

4. Shityakov, S.; Bigdelian, E.; Hussein, A.A.; Hussain, M.B.; Tripathi, Y.C.; Khan, M.U.; Shariati, M.A. Phytochemical and pharmacological attributes of piperine: A bioactive ingredient of black pepper. Eur. J. Med. Chem. 2019, 176, 149-161. [CrossRef]

5. Takooree, H.; Aumeeruddy, M.Z.; Rengasamy, K.R.R.; Venugopala, K.N.; Jeewon, R.; Zengin, G.; Mahomoodally, M.F. A systematic review on black pepper (Piper nigrum L.): From folk uses to pharmacological applications. Crit. Rev. Food Sci. Nutr. 2019, 59, S210-S243. [CrossRef]

6. Assaraf, Y.G.; Brozovic, A.; Goncalves, A.C.; Jurkovicova, D.; Line, A.; Machuqueiro, M.; Saponara, S.; Sarmento-Ribeiro, A.B.; Xavier, C.P.R.; Vasconcelos, M.H. The multi-factorial nature of clinical multidrug resistance in cancer. Drug Resist. Updat. 2019, 46, 100645. [CrossRef]

7. Li, S.; Lei, Y.; Jia, Y.; Li, N.; Wink, M.; Ma, Y. Piperine, a piperidine alkaloid from Piper nigrum re-sensitizes P-gp, MRP1 and BCRP dependent multidrug resistant cancer cells. Phytomedicine 2011, 19, 83-87. [CrossRef]

8. Bhardwaj, R.K.; Glaeser, H.; Becquemont, L.; Klotz, U.; Gupta, S.K.; Fromm, M.F. Piperine, a major constituent of black pepper, inhibits human P-glycoprotein and CYP3A4. J. Pharmacol. Exp. Ther. 2002, 302, 645-650. [CrossRef]

9. Makhov, P.; Golovine, K.; Canter, D.; Kutikov, A.; Simhan, J.; Corlew, M.M.; Uzzo, R.G.; Kolenko, V.M. Co-administration of piperine and docetaxel results in improved anti-tumor efficacy via inhibition of CYP3A4 activity. Prostate 2012, 72, 661-667. [CrossRef]

10. Volak, L.P.; Ghirmai, S.; Cashman, J.R.; Court, M.H. Curcuminoids inhibit multiple human cytochromes P450, UDP-glucuronosyltransferase, and sulfotransferase enzymes, whereas piperine is a relatively selective CYP3A4 inhibitor. Drug Metab. Dispos. 2008, 36, 1594-1605. [CrossRef]

11. Mohammadi, M.; Najafi, H.; Mohamadi Yarijani, Z.; Vaezi, G.; Hojati, V. Piperine pretreatment attenuates renal ischemia-reperfusion induced liver injury. Heliyon 2019, 5, e02180. [CrossRef]

12. Verma, N.; Bal, S.; Gupta, R.; Aggarwal, N.; Yadav, A. Antioxidative Effects of Piperine against Cadmium-Induced Oxidative Stress in Cultured Human Peripheral Blood Lymphocytes. J. Diet. Suppl. 2020, 17, 41-52. [CrossRef]

13. Umar, S.; Golam Sarwar, A.H.; Umar, K.; Ahmad, N.; Sajad, M.; Ahmad, S.; Katiyar, C.K.; Khan, H.A. Piperine ameliorates oxidative stress, inflammation and histological outcome in collagen induced arthritis. Cell Immunol. 2013, 284, 51-59. [CrossRef]

14. Gutierrez, R.M.; Gonzalez, A.M.; Hoyo-Vadillo, C. Alkaloids from piper: A review of its phytochemistry and pharmacology. Mini Rev. Med. Chem. 2013, 13, 163-193. [CrossRef]

15. Tasleem, F.; Azhar, I.; Ali, S.N.; Perveen, S.; Mahmood, Z.A. Analgesic and anti-inflammatory activities of Piper nigrum L. Asian Pac. J. Trop. Med. 2014, 7S1, S461-S468. [CrossRef]

16. Freire-de-Lima, L.; Ribeiro, T.S.; Rocha, G.M.; Brandao, B.A.; Romeiro, A.; Mendonca-Previato, L.; Previato, J.O.; de Lima, M.E.; de Carvalho, T.M.; Heise, N. The toxic effects of piperine against Trypanosoma cruzi: Ultrastructural alterations and reversible blockage of cytokinesis in epimastigote forms. Parasitol. Res. 2008, 102, 1059-1067. [CrossRef]

17. Ribeiro, T.S.; Freire-de-Lima, L.; Previato, J.O.; Mendonca-Previato, L.; Heise, N.; de Lima, M.E. Toxic effects of natural piperine and its derivatives on epimastigotes and amastigotes of Trypanosoma cruzi. Bioorg Med. Chem. Lett. 2004, 14, 3555-3558. [CrossRef]

18. Choi, J.W.; Lee, S.K.; Kim, M.J.; Kim, D.G.; Shin, J.Y.; Zhou, Z.; Jo, I.J.; Song, H.J.; Bae, G.S.; Park, S.J. Piperine ameliorates the severity of fibrosis via inhibition of TGFbeta/SMAD signaling in a mouse model of chronic pancreatitis. Mol. Med. Rep. 2019, 20, 3709-3718. [CrossRef]

19. Ying, X.; Yu, K.; Chen, X.; Chen, H.; Hong, J.; Cheng, S.; Peng, L. Piperine inhibits LPS induced expression of inflammatory mediators in RAW 264.7 cells. Cell Immunol. 2013, 285, 49-54. [CrossRef] 
20. Abdelhamed, S.; Yokoyama, S.; Refaat, A.; Ogura, K.; Yagita, H.; Awale, S.; Saiki, I. Piperine enhances the efficacy of TRAIL-based therapy for triple-negative breast cancer cells. Anticancer Res. 2014, 34, 1893-1899.

21. Fofaria, N.M.; Kim, S.H.; Srivastava, S.K. Piperine causes G1 phase cell cycle arrest and apoptosis in melanoma cells through checkpoint kinase-1 activation. PLoS ONE 2014, 9, e94298. [CrossRef]

22. Greenshields, A.L.; Doucette, C.D.; Sutton, K.M.; Madera, L.; Annan, H.; Yaffe, P.B.; Knickle, A.F.; Dong, Z.; Hoskin, D.W. Piperine inhibits the growth and motility of triple-negative breast cancer cells. Cancer Lett. 2015, 357, 129-140. [CrossRef]

23. Yaffe, P.B.; Power Coombs, M.R.; Doucette, C.D.; Walsh, M.; Hoskin, D.W. Piperine, an alkaloid from black pepper, inhibits growth of human colon cancer cells via G1 arrest and apoptosis triggered by endoplasmic reticulum stress. Mol. Carcinog. 2015, 54, 1070-1085. [CrossRef]

24. Ouyang, D.Y.; Zeng, L.H.; Pan, H.; Xu, L.H.; Wang, Y.; Liu, K.P.; He, X.H. Piperine inhibits the proliferation of human prostate cancer cells via induction of cell cycle arrest and autophagy. Food Chem. Toxicol. 2013, 60, 424-430. [CrossRef]

25. Lai, L.H.; Fu, Q.H.; Liu, Y.; Jiang, K.; Guo, Q.M.; Chen, Q.Y.; Yan, B.; Wang, Q.Q.; Shen, J.G. Piperine suppresses tumor growth and metastasis in vitro and in vivo in a $4 \mathrm{~T} 1$ murine breast cancer model. Acta Pharmacol. Sin. 2012, 33, 523-530. [CrossRef]

26. Yang, S.; Zhang, J.J.; Huang, X.Y. Mouse models for tumor metastasis. Methods Mol. Biol. 2012, 928, $221-228$. [CrossRef]

27. Park, M.K.; Lee, C.H.; Lee, H. Mouse models of breast cancer in preclinical research. Lab. Anim. Res. 2018, 34, 160-165. [CrossRef]

28. Selvendiran, K.; Banu, S.M.; Sakthisekaran, D. Protective effect of piperine on benzo(a)pyrene-induced lung carcinogenesis in Swiss albino mice. Clin. Chim. Acta 2004, 350, 73-78. [CrossRef]

29. Doucette, C.D.; Hilchie, A.L.; Liwski, R.; Hoskin, D.W. Piperine, a dietary phytochemical, inhibits angiogenesis. J. Nutr. Biochem. 2013, 24, 231-239. [CrossRef]

30. Zhang, J.; Zhu, X.; Li, H.; Li, B.; Sun, L.; Xie, T.; Zhu, T.; Zhou, H.; Ye, Z. Piperine inhibits proliferation of human osteosarcoma cells via G2/M phase arrest and metastasis by suppressing MMP-2/-9 expression. Int. Immunopharmacol. 2015, 24, 50-58. [CrossRef]

31. Kakarala, M.; Brenner, D.E.; Korkaya, H.; Cheng, C.; Tazi, K.; Ginestier, C.; Liu, S.; Dontu, G.; Wicha, M.S. Targeting breast stem cells with the cancer preventive compounds curcumin and piperine. Breast Cancer Res. Treat. 2010, 122, 777-785. [CrossRef] [PubMed]

32. Hwang, Y.P.; Yun, H.J.; Kim, H.G.; Han, E.H.; Choi, J.H.; Chung, Y.C.; Jeong, H.G. Suppression of phorbol-12-myristate-13-acetate-induced tumor cell invasion by piperine via the inhibition of PKCalpha/ERK1/2-dependent matrix metalloproteinase-9 expression. Toxicol. Lett. 2011, 203,9-19. [CrossRef]

33. Thiery, J.P.; Sleeman, J.P. Complex networks orchestrate epithelial-mesenchymal transitions. Nat. Rev. Mol. Cell Biol. 2006, 7, 131-142. [CrossRef] [PubMed]

34. Scheel, C.; Weinberg, R.A. Cancer stem cells and epithelial-mesenchymal transition: Concepts and molecular links. Semin. Cancer Biol. 2012, 22, 396-403. [CrossRef]

35. Katsuno, Y.; Lamouille, S.; Derynck, R. TGF-beta signaling and epithelial-mesenchymal transition in cancer progression. Curr. Opin. Oncol. 2013, 25, 76-84. [CrossRef]

36. Samatov, T.R.; Tonevitsky, A.G.; Schumacher, U. Epithelial-mesenchymal transition: Focus on metastatic cascade, alternative splicing, non-coding RNAs and modulating compounds. Mol. Cancer 2013, 12, 107. [CrossRef]

37. Fischer, K.R.; Durrans, A.; Lee, S.; Sheng, J.; Li, F.; Wong, S.T.; Choi, H.; El Rayes, T.; Ryu, S.; Troeger, J.; et al. Epithelial-to-mesenchymal transition is not required for lung metastasis but contributes to chemoresistance. Nature 2015, 527, 472-476. [CrossRef]

38. Lamouille, S.; Xu, J.; Derynck, R. Molecular mechanisms of epithelial-mesenchymal transition. Nat. Rev. Mol. Cell Biol. 2014, 15, 178-196. [CrossRef]

39. Lee, J.M.; Dedhar, S.; Kalluri, R.; Thompson, E.W. The epithelial-mesenchymal transition: New insights in signaling, development, and disease. J. Cell Biol. 2006, 172, 973-981. [CrossRef]

40. Zielinska, H.A.; Bahl, A.; Holly, J.M.; Perks, C.M. Epithelial-to-mesenchymal transition in breast cancer: A role for insulin-like growth factor I and insulin-like growth factor-binding protein 3? Breast Cancer 2015, 7, 9-19. [CrossRef] 
41. Xu, J.; Lamouille, S.; Derynck, R. TGF-beta-induced epithelial to mesenchymal transition. Cell Res. 2009, 19, 156-172. [CrossRef] [PubMed]

42. Chaudhury, A.; Howe, P.H. The tale of transforming growth factor-beta (TGFbeta) signaling: A soigne enigma. IUBMB Life 2009, 61, 929-939. [CrossRef] [PubMed]

43. Sheen, Y.Y.; Kim, M.J.; Park, S.A.; Park, S.Y.; Nam, J.S. Targeting the Transforming Growth Factor-beta Signaling in Cancer Therapy. Biomol. Ther. 2013, 21, 323-331. [CrossRef] [PubMed]

44. Pradeep, C.R.; Kuttan, G. Effect of piperine on the inhibition of lung metastasis induced B16F-10 melanoma cells in mice. Clin. Exp. Metastasis 2002, 19, 703-708. [CrossRef]

45. Khamis, A.A.A.; Ali, E.M.M.; El-Moneim, M.A.A.; Abd-Alhaseeb, M.M.; El-Magd, M.A.; Salim, E.I. Hesperidin, piperine and bee venom synergistically potentiate the anticancer effect of tamoxifen against breast cancer cells. Biomed. Pharmacother. 2018, 105, 1335-1343. [CrossRef]

46. Sedeky, A.S.; Khalil, I.A.; Hefnawy, A.; El-Sherbiny, I.M. Development of core-shell nanocarrier system for augmenting piperine cytotoxic activity against human brain cancer cell line. Eur. J. Pharm. Sci. 2018, 118, 103-112. [CrossRef]

47. Li, H.; Krstin, S.; Wang, S.; Wink, M. Capsaicin and Piperine Can Overcome Multidrug Resistance in Cancer Cells to Doxorubicin. Molecules 2018, 23, 557. [CrossRef]

48. Li, C.; Wang, Z.; Wang, Q.; Ka Yan Ho, R.L.; Huang, Y.; Chow, M.S.S.; Kei Lam, C.W.; Zuo, Z. Enhanced anti-tumor efficacy and mechanisms associated with docetaxel-piperine combination- in vitro and in vivo investigation using a taxane-resistant prostate cancer model. Oncotarget 2018, 9, 3338-3352. [CrossRef]

49. Du, B.; Shim, J.S. Targeting Epithelial-Mesenchymal Transition (EMT) to Overcome Drug Resistance in Cancer. Molecules 2016, 21, 965. [CrossRef]

50. Hu, M.; Peng, S.; He, Y.; Qin, M.; Cong, X.; Xing, Y.; Liu, M.; Yi, Z. Lycorine is a novel inhibitor of the growth and metastasis of hormone-refractory prostate cancer. Oncotarget 2015, 6, 15348-15361. [CrossRef]

51. Liu, L.; Li, H.; Guo, Z.; Ma, X.; Cao, N.; Zheng, Y.; Geng, S.; Duan, Y.; Han, G.; Du, G. The Combination of Three Natural Compounds Effectively Prevented Lung Carcinogenesis by Optimal Wound Healing. PLoS ONE 2015, 10, e0143438. [CrossRef] [PubMed]

52. Ben Trivedi, A.; Kitabatake, N.; Doi, E. Toxicity of dimethyl sulfoxide as a solvent in bioassay system with HeLa cells evaluated colorimetrically with 3-(4,5-dimethylthiazol-2-yl)-2,5-diphenyl-tetrazolium bromide. Agric. Biol. Chem. 1990, 54, 2961-2966. [CrossRef] [PubMed]

53. Mosmann, T. Rapid colorimetric assay for cellular growth and survival: Application to proliferation and cytotoxicity assays. J. Immunol. Methods 1983, 65, 55-63. [CrossRef]

54. Oladipupo, S.S.; Hu, S.; Santeford, A.C.; Yao, J.; Kovalski, J.R.; Shohet, R.V.; Maslov, K.; Wang, L.V.; Arbeit, J.M. Conditional HIF-1 induction produces multistage neovascularization with stage-specific sensitivity to VEGFR inhibitors and myeloid cell independence. Blood 2011, 117, 4142-4153. [CrossRef] [PubMed]

55. Freire-de-Lima, L.; Gelfenbeyn, K.; Ding, Y.; Mandel, U.; Clausen, H.; Handa, K.; Hakomori, S.I. Involvement of O-glycosylation defining oncofetal fibronectin in epithelial-mesenchymal transition process. Proc. Natl. Acad. Sci. USA 2011, 108, 17690-17695. [CrossRef]

56. Alisson-Silva, F.; Freire-de-Lima, L.; Donadio, J.L.; Lucena, M.C.; Penha, L.; Sa-Diniz, J.N.; Dias, W.B.; Todeschini, A.R. Increase of O-glycosylated oncofetal fibronectin in high glucose-induced epithelial-mesenchymal transition of cultured human epithelial cells. PLoS ONE 2013, 8, e60471. [CrossRef]

57. Guan, F.; Handa, K.; Hakomori, S.I. Specific glycosphingolipids mediate epithelial-to-mesenchymal transition of human and mouse epithelial cell lines. Proc. Natl. Acad. Sci. USA 2009, 106, 7461-7466. [CrossRef]

58. Ding, Y.; Gelfenbeyn, K.; Freire-de-Lima, L.; Handa, K.; Hakomori, S.I. Induction of epithelial-mesenchymal transition with O-glycosylated oncofetal fibronectin. FEBS Lett. 2012, 586, 1813-1820. [CrossRef]

59. Kasai, H.; Allen, J.T.; Mason, R.M.; Kamimura, T.; Zhang, Z. TGF-beta1 induces human alveolar epithelial to mesenchymal cell transition (EMT). Respir. Res. 2005, 6, 56. [CrossRef]

60. Zhang, Y.E. Non-Smad pathways in TGF-beta signaling. Cell Res. 2009, 19, 128-139. [CrossRef]

61. Moustakas, A.; Heldin, C.H. Non-Smad TGF-beta signals. J. Cell Sci. 2005, 118, 3573-3584. [CrossRef] [PubMed]

62. Ikushima, H.; Miyazono, K. Cellular context-dependent "colors" of transforming growth factor-beta signaling. Cancer Sci. 2010, 101, 306-312. [CrossRef] [PubMed] 
63. Nishida, N.; Kitano, M.; Sakurai, T.; Kudo, M. Molecular Mechanism and Prediction of Sorafenib Chemoresistance in Human Hepatocellular Carcinoma. Dig. Dis. 2015, 33, 771-779. [CrossRef] [PubMed]

64. Neuzillet, C.; Tijeras-Raballand, A.; de Mestier, L.; Cros, J.; Faivre, S.; Raymond, E. MEK in cancer and cancer therapy. Pharmacol. Ther. 2014, 141, 160-171. [CrossRef]

65. Moselhy, J.; Srinivasan, S.; Ankem, M.K.; Damodaran, C. Natural Products That Target Cancer Stem Cells. Anticancer Res. 2015, 35, 5773-5788.

66. Ye, X.; Weinberg, R.A. Epithelial-Mesenchymal Plasticity: A Central Regulator of Cancer Progression. Trends Cell Biol. 2015, 25, 675-686. [CrossRef]

67. Freire-de-Lima, L. Sweet and sour: The impact of differential glycosylation in cancer cells undergoing epithelial-mesenchymal transition. Front. Oncol. 2014, 4, 59. [CrossRef]

68. Ko, H. Geraniin inhibits TGF-beta1-induced epithelial-mesenchymal transition and suppresses A549 lung cancer migration, invasion and anoikis resistance. Bioorg. Med. Chem. Lett. 2015, 25, 3529-3534. [CrossRef]

69. Zhao, L.; Liu, S.; Che, X.; Hou, K.; Ma, Y.; Li, C.; Wen, T.; Fan, Y.; Hu, X.; Liu, Y.; et al. Bufalin inhibits TGF-beta-induced epithelial-to-mesenchymal transition and migration in human lung cancer A549 cells by downregulating TGF-beta receptors. Int. J. Mol. Med. 2015, 36, 645-652. [CrossRef]

70. Yang, H.; Zhan, L.; Yang, T.; Wang, L.; Li, C.; Zhao, J.; Lei, Z.; Li, X.; Zhang, H.T. Ski prevents TGF-beta-induced EMT and cell invasion by repressing SMAD-dependent signaling in non-small cell lung cancer. Oncol. Rep. 2015, 34, 87-94. [CrossRef]

71. Ranjan, A.; Fofaria, N.M.; Kim, S.H.; Srivastava, S.K. Modulation of signal transduction pathways by natural compounds in cancer. Chin. J. Nat. Med. 2015, 13, 730-742. [CrossRef]

72. Scarpa, E.S.; Ninfali, P. Phytochemicals as Innovative Therapeutic Tools against Cancer Stem Cells. Int. J. Mol. Sci. 2015, 16, 15727-15742. [CrossRef]

73. Qiu, S.; Sun, H.; Zhang, A.H.; Xu, H.Y.; Yan, G.L.; Han, Y.; Wang, X.J. Natural alkaloids: Basic aspects, biological roles, and future perspectives. Chin. J. Nat. Med. 2014, 12, 401-406. [CrossRef]

74. Chen, T.; You, Y.; Jiang, H.; Wang, Z.Z. Epithelial-mesenchymal transition (EMT): A biological process in the development, stem cell differentiation, and tumorigenesis. J. Cell. Physiol. 2017, 232, 3261-3272. [CrossRef] [PubMed]

75. Xia, Y.; Khoi, P.N.; Yoon, H.J.; Lian, S.; Joo, Y.E.; Chay, K.O.; Kim, K.K.; Jung, Y.D. Piperine inhibits IL-1beta-induced IL-6 expression by suppressing p38 MAPK and STAT3 activation in gastric cancer cells. Mol. Cell. Biochem. 2015, 398, 147-156. [CrossRef] [PubMed]

76. Thiery, J.P.; Acloque, H.; Huang, R.Y.; Nieto, M.A. Epithelial-mesenchymal transitions in development and disease. Cell 2009, 139, 871-890. [CrossRef] [PubMed]

77. Augsburger, F.; Randi, E.B.; Jendly, M.; Ascencao, K.; Dilek, N.; Szabo, C. Role of 3-Mercaptopyruvate Sulfurtransferase in the Regulation of Proliferation, Migration, and Bioenergetics in Murine Colon Cancer Cells. Biomolecules 2020, 10, 447. [CrossRef]

78. Nozaki, E.; Kobayashi, T.; Ohnishi, H.; Ohtsuka, K.; Masaki, T.; Watanabe, T.; Sugiyama, M. C-X-C motif receptor $3 \mathrm{~A}$ enhances proliferation and invasiveness of colorectal cancer cells, and is mediated by C-X-C motif ligand 10. Oncol. Lett. 2020, 19, 2495-2501. [CrossRef]

79. Li, Y.; Liu, J.J.; Zhou, J.H.; Chen, R.; Cen, C.Q. LncRNA HULC induces the progression of osteosarcoma by regulating the miR-372-3p/HMGB1 signalling axis. Mol. Med. 2020, 26, 26. [CrossRef]

80. Park, S.Y.; Yoon, S.J.; Freire-de-Lima, L.; Kim, J.H.; Hakomori, S.I. Control of cell motility by interaction of gangliosides, tetraspanins, and epidermal growth factor receptor in A431 versus KB epidermoid tumor cells. Carbohydr. Res. 2009, 344, 1479-1486. [CrossRef]

81. Pradeep, C.R.; Kuttan, G. Piperine is a potent inhibitor of nuclear factor-kappaB (NF-kappaB), c-Fos, CREB, ATF-2 and proinflammatory cytokine gene expression in B16F-10 melanoma cells. Int. Immunopharmacol. 2004, 4, 1795-1803. [CrossRef] [PubMed]

82. Samykutty, A.; Shetty, A.V.; Dakshinamoorthy, G.; Bartik, M.M.; Johnson, G.L.; Webb, B.; Zheng, G.; Chen, A.; Kalyanasundaram, R.; Munirathinam, G. Piperine, a Bioactive Component of Pepper Spice Exerts Therapeutic Effects on Androgen Dependent and Androgen Independent Prostate Cancer Cells. PLoS ONE 2013, 8, e65889. [CrossRef] [PubMed]

83. Hou, X.F.; Pan, H.; Xu, L.H.; Zha, Q.B.; He, X.H.; Ouyang, D.Y. Piperine Suppresses the Expression of CXCL8 in Lipopolysaccharide-Activated SW480 and HT-29 Cells via Downregulating the Mitogen-Activated Protein Kinase Pathways. Inflammation 2015, 38, 1093-1102. [CrossRef] [PubMed] 
84. Bae, G.S.; Kim, J.J.; Park, K.C.; Koo, B.S.; Jo, I.J.; Choi, S.B.; Lee, C.H.; Jung, W.S.; Cho, J.H.; Hong, S.H.; et al. Piperine inhibits lipopolysaccharide-induced maturation of bone-marrow-derived dendritic cells through inhibition of ERK and JNK activation. Phytother. Res. 2012, 26, 1893-1897. [CrossRef] [PubMed]

85. Lee, K.P.; Lee, K.; Park, W.H.; Kim, H.; Hong, H. Piperine inhibits platelet-derived growth factor-BB-induced proliferation and migration in vascular smooth muscle cells. J. Med. Food 2015, 18, 208-215. [CrossRef]

86. Saitoh, M. Epithelial-mesenchymal transition is regulated at post-transcriptional levels by transforming growth factor-beta signaling during tumor progression. Cancer Sci. 2015, 106, 481-488. [CrossRef]

87. Derynck, R.; Muthusamy, B.P.; Saeteurn, K.Y. Signaling pathway cooperation in TGF-beta-induced epithelial-mesenchymal transition. Curr. Opin. Cell Biol. 2014, 31, 56-66. [CrossRef]

88. Saxena, M.; Stephens, M.A.; Pathak, H.; Rangarajan, A. Transcription factors that mediate epithelial-mesenchymal transition lead to multidrug resistance by upregulating ABC transporters. Cell Death Dis. 2011, 2, e179. [CrossRef]

89. Ma, J.L.; Zeng, S.; Zhang, Y.; Deng, G.L.; Shen, H. Epithelial-mesenchymal transition plays a critical role in drug resistance of hepatocellular carcinoma cells to oxaliplatin. Tumor Biol. 2016, 37, 6177-6184. [CrossRef]

90. Zhou, J.; Wang, J.; Zeng, Y.; Zhang, X.; Hu, Q.; Zheng, J.; Chen, B.; Xie, B.; Zhang, W.M. Implication of epithelial-mesenchymal transition in IGF1R-induced resistance to EGFR-TKIs in advanced non-small cell lung cancer. Oncotarget 2015, 6, 44332-44345. [CrossRef]

91. Li, J.; Liu, H.; Yu, J.; Yu, H. Chemoresistance to doxorubicin induces epithelial-mesenchymal transition via upregulation of transforming growth factor beta signaling in HCT116 colon cancer cells. Mol. Med. Rep. 2015, 12, 192-198. [CrossRef] [PubMed]

(C) 2020 by the authors. Licensee MDPI, Basel, Switzerland. This article is an open access article distributed under the terms and conditions of the Creative Commons Attribution (CC BY) license (http://creativecommons.org/licenses/by/4.0/). 